\title{
iorhs
}

\section{The Impact of COVID-19 on Youth Unemployment in Albania}

\author{
Geranda Mulla \\ PhD Candidate, Faculty of Social Science, University of Tirana, Albania
}

\begin{abstract}
Young people are socially and economically impacted from the pandemic situation. The global health crises affected almost all aspects of young people lives in short and long terms. The aim of this study is to explore the impact of COVID-19 on youth unemployment in Albania. It also focuses on the need to strengthen public employment policies for a smooth transition from school to work. Using the snowball sampling strategy the questionnaire was completed by 534 young people living in Tirana. $31 \%$ of them were unemployed and out of these $45 \%$ lost their job as a result of the pandemic. The risk of being excluded from labour market has been increased significantly for recent graduated $(83 \%)$ and particularly for female young people. Transitioning to the labour market is still a challenge. Therefore, it is important that policy makers take effective measure to support young graduated people to overcome the pandemic effects and develop them through upskilling and reskilling programmes.
\end{abstract}

Keywords: COVID-19; youth unemployment; school-to-work transition; young graduated people; upskilling and reskilling programmes

\section{Introduction}

Traditionally youth unemployment has not been considered as a major problem. Nonetheless, in order to stimulate a global economic growth and improve the livelihood in general for the entire population it is crucial to support young people to find and keep the job. According to European Commission 2020 economic forecast, the European Union economy would have shrink to $8.3 \%$ in 2020 . In this summer communication is predicted that the economy growth in 2021 will be $6.3 \%$, slightly less robust than projected earlier in the spring (European Commission, 2020).

The impacts of COVID-19 are, and will continue to be, felt most harshly by young people already living in difficult and/or disadvantaged circumstances ${ }^{1}$. Young people are disproportionately affected by the COVID-19 crisis, with multiple shocks including disruption to education and training, employment and income losses, and greater difficulties

Compact for Young People in Humanitarian Action: COVID-19: Working with and for young people, Unated Nations, May 2020. 


\section{iorhs}

\section{4th International Conference On Research In HUMANITIES \& SOCIAL SCIENCES}

in finding a job (ILO Monitor, 2020) ${ }^{2}$. The number of young people currently facing the choice between further study and exposure to the labour market is large and the group is diverse and now are entering a market in decline and with limited opportunities. ${ }^{3}$

The European Union unemployment rate in February 2021 is $7.5 \%$. The rate for unemployed women is higher $(7.9 \%)$ than men $7.1 \%$ (Eurostat, 2021). Referring to the data published by European Parliament the youth unemployment rate (15-24) prior to the Covid-19 was $14.9 \%$, down from its peak of 24.4 in 2013. In February 2021, the youth unemployment rate was $17.2 \%$ in the EU and $17.3 \%$ in the euro area, compared with $17.4 \%$ in both areas in the previous month. Compared with January 2021, youth unemployment decreased by 34000 in the EU and by 9000 in the euro area. Compared with February 2020, youth unemployment increased by 230000 in the EU and by 177000 in the euro area (Eurostat, 2021).

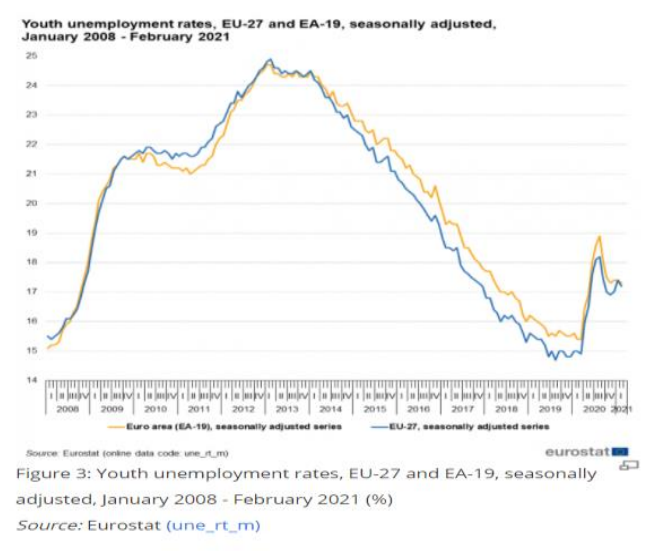

In Albania youth unemployment is rising. The current COVID-19 crises has affected all especially young people. According to the data provided by the Albanian National Institute of Statistics (INSTAT) youth unemployment rate for a period of three last years has been increased. Graphic 1 present the unemployement of young people of age between 15 to 29 years old who officially were registered as unemployed. As showed below the highest level of the Albanian youth unemployed has been reached during the second quarter through out the forth quater of 2020 year. The only exeption is seen while comparing the 2020 first quarter with 2018. However, the youth unemployement rate is still higher comparing with same period in 2019.

Graphic1. Share of youth unemployed in Albania in numbers

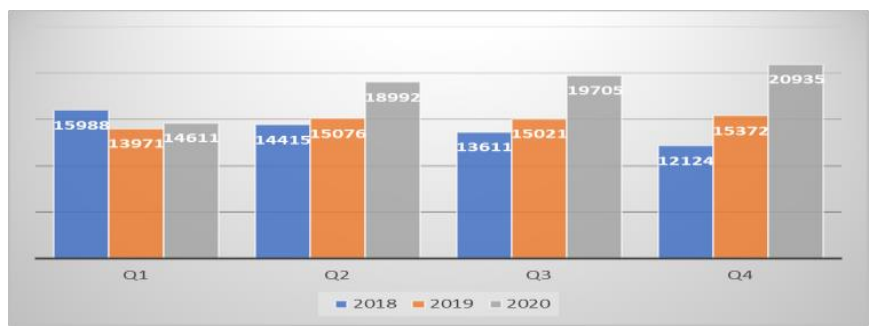

\footnotetext{
${ }^{2}$ Monitor, ILO (2020). COVID-19 and the world of work. Updated estimates and analysis.

${ }^{3}$ Henehan, K. (2020). Class of 2020: Education leavers in the current crisis.
} 


\title{
iorhs
}

\section{4th International Conference On Research In HUMANITIES \& SOCIAL SCIENCES}

\author{
Source: INSTAT
}

\section{Literature Review}

The studies and data related to youth unemployment in Albania are relatively broad. On the other hand also the studies on COVID are relatively broad. Nonetheless, the impact of COVID on youth unemployment with evidence based studies is somehow scarce.

Unemployment generally, but especially during one's youth, has far-reaching consequences for individuals, society as a whole and economic development ${ }^{4}$. Those entering the labour market during a recession can expect lower wages and fewer opportunities for career progression, and the impact can last a lifetime ${ }^{5}$. Being unemployed at a young age can have long-lasting "scarring effects" in career paths and future earnings ${ }^{6}$. Young people also are more likely to work in non-standard employment, such as temporary or part-time work, facing a higher risk of job and income loss (OECD, 2020).

To combat the COVID conceguences "in support of employees and / or other strata affected by the suspension of work processes nationwide, including the needy, the unemployed and communities " the Albanian government have ensured ALL 6.5 billion Fund for the AntiCOVID Social Package. Also, the State Budget Reserve Fund have dedicated other 1 billion ALL for the creation of space for financing the necessary expenditures of unforeseen character, for the following months. The Emergency Fund received 2 billion ALL reallocations to provide food supply to certain communities, which will be affected by the pandemic, or for families with economic assistance and lonely pensioners who will need direct assistance. Nonetheles, it is important to emphasize that there cannot be reported for a clear impact that these measures have had for youth in Albania (Partners Albania for Change and Development, 2021).

Furthermore, the transition from school to work is still a challenge. The new Digital Education Action Plan 2021-2027 introduced by European Commision addresses many challenges and implementing these strategies may pave the way towards a more flexible and adaptable approach to education. We need to apply and develop critical applied research methodologies and create design principles for democratic and emancipatory digitalization of education (Teräs et all, 2020).

There is a discrepancy between the numbers of graduations, their field of study and the professions required in the labour market. Young people wait up to an average of four years or more before finding their first job7. It is noticed that there is a trend of decreasing the numbers of young graduated profesionals ( from 35388 in 2017 to 34891 in 2019). Yet again the numbers are still high and not in porpotion with open vacancies. Also, the field in which

\footnotetext{
${ }^{4}$ Tamesberger, D., \& Bacher, J. (2020). COVID-19 Crisis: How to Avoid a 'Lost Generation'. Intereconomics, 55(4), 232-238.

${ }^{5}$ Brotherhood of St.Laurence, (2020). Youth unemployment monitor. COVID the great disruptor. Another blow to youth employment.

${ }^{6}$ OECD (2020), "Youth and COVID-19 Response, Recovery and Resilience".

${ }^{7}$ Albanian National Strategy for Employment and Skills 2014 - 2020
} 


\section{iorhs}

\section{4th International Conference On Research In HUMANITIES \& SOCIAL SCIENCES}

more students have been graduated are Business, Administration and Law. Thus, it indicates an urgent need for more counselling sessions while young people choose their educational path. According to a study held in Albania in 2020 the most important skills needed to develop for graduate level are customer focus and team spirit (AIMIS, 2020). Therefore, upskilling and reskilling is very important to better understand what is required from the labour market and how government policies can respond to these demands.

\section{Methodology}

The sampling strategy was choosen to gather the data of this study. The period in which the survey was completed by young people in Albania was more two months and specifically from January to March 2021. The target population was young people of the age of 15-29 years old with a specification of living in Tirana which is the capital city of Albania.

The desired sample was 500. However, the survey reached out to 639 young people and out of them 534 fully completed the questionnaire. SPSS software was used to analyze the data of only those 534 questionnaires that were fully completed. In combination with literature review method the study will provide an overview of young people that were affected from COVID-19 in Albania. Age, gender, marital status, education and the period of unemployment are some of the variables that had a statistical significance level.

\section{Results and Discussion}

$31 \%$ of the young people of this study were unemployed and out of these $45 \%$ lost their job as a result of the pandemic. $81 \%$ are female and $19 \%$ are male. The highest percentages in relation to the age are for the group of 20-24 years old, covering $60 \%$ of the total. The second age group of 34\% include the group of 15-19 years old and the lowest rate of $6 \%$ is for the group of 25-29 years old. $89 \%$ of sample are single. $11 \%$ are married and only $1 \%$ divorced. Regarding the education level only $9 \%$ are at the lower level with mandatory education, followed by $29 \%$ with a high school diploma and the rest of $63 \%$ are with higher education (Bachelor or Master Diploma).

Furthermore, the data analyzed shows that $83 \%$ of young people who are unemployed due to COVID-19 are just recently graduated and specifically in the 4 latest years 2016-2020. 53\% are more than a year unemployed which clearly indicates and relates to the difficulties that young people are facing to enter into the labour market due to COVID-19.

On the gender perspective the female young people are much more risked (89\%) than male who are recently graduated (56\%). For an Albanian young female the transition to the labour market is more difficult than for a male. There are not sufficient data to explain the reason behind this finding and understand the gender differences and the nature of these differences. The state have taken several steps to prevent gender discrimination and expand employment and entrepreneurial opportunities for women. However, other studies have revealed that in general women in Albania are more discriminated in the labour market. 


\section{iorhs}

4th International Conference On Research In

7-9 May 2021

HUMANITIES \& SOCIAL SCIENCES

Milan - Italy

\begin{tabular}{|c|c|c|c|}
\hline Variable & Female & Male & Total \\
\hline \multicolumn{4}{|l|}{ Age } \\
\hline $15-19$ & $32 \%$ & $44 \%$ & $34 \%$ \\
\hline $20-24$ & $63 \%$ & $49 \%$ & $60 \%$ \\
\hline $25-29$ & $5 \%$ & $7 \%$ & $6 \%$ \\
\hline \multicolumn{4}{|l|}{ Status } \\
\hline Single & $94 \%$ & $64 \%$ & $89 \%$ \\
\hline Divorced & - & $4 \%$ & $1 \%$ \\
\hline Married & $6 \%$ & $33 \%$ & $11 \%$ \\
\hline \multicolumn{4}{|l|}{ Education } \\
\hline Mandatory & $10 \%$ & $4 \%$ & $9 \%$ \\
\hline High School & $31 \%$ & $22 \%$ & $29 \%$ \\
\hline Bachelor/Master & $60 \%$ & $75 \%$ & $63 \%$ \\
\hline \multicolumn{4}{|l|}{ Finalization of studies } \\
\hline Between $2010-2015$ & $11 \%$ & $44 \%$ & $17 \%$ \\
\hline Between $2016-2020$ & $89 \%$ & $56 \%$ & $83 \%$ \\
\hline \multicolumn{4}{|c|}{ Period of being unemployed } \\
\hline Less than 4 weeks & $6.69 \%$ & $10.75 \%$ & $7.45 \%$ \\
\hline $1-3$ months & $9.31 \%$ & $3.28 \%$ & $8.17 \%$ \\
\hline 3-6 months & $12.86 \%$ & $34.36 \%$ & $16.91 \%$ \\
\hline 6-9 months & $7.33 \%$ & $2.21 \%$ & $6.36 \%$ \\
\hline 9-12 months & $7.39 \%$ & $7.35 \%$ & $7.38 \%$ \\
\hline More than a year & $56.43 \%$ & $42.05 \%$ & $53.72 \%$ \\
\hline
\end{tabular}

\section{Conclusion (TNR 14pt., bold)}

The COVID recession made that school leavers miss out the opportunities to land their first job. The risk of being excluded from labour market has been increased significantly for recent graduated (83\%) and particularly for female young people. Furthermore, the female category is much more impacted from COVID-19 conseguences and have more difficulties to re-enter to the labout market. It is necessary to have a better coordination and cooperation between private sector and government institutions, both at central and local level. This collaboration would have supported specifically the category of youth aged 15-29 to better understand the labour market demands. Thus, it would have a significant added value while the young people choose their future professions and of course when the transition from school-to-work take place. In order to achieve an economic growth another crucial aspects is the creation of jobs that will fight youth unemployment. Empowering young people by formulating proper upskilling and reskilling plans will enhance the chances for gender quality in education, employement and decision making. 


\section{iorhs}

\section{4th International Conference On Research In HUMANITIES \& SOCIAL SCIENCES}

\section{REFERENCES}

Albanian National Institute of Statistics. (2019). Labour Market 2018.

Albanian National Strategy for Employment and Skills 2014-2020

AIMS Albania. (2020). Upskilling and Reskilling in the New Normal

Brotherhood of St.Laurence, (2020). Youth unemployment monitor. COVID the great disruptor. Another blow to youth employment.

Compact for Young People in Humanitarian Action: COVID-19: Working with and for young people, Unated Nations, May 2020.

European Commission. (2020). Digital Education Action Plan 2021-2027

Henehan, K. (2020). Class of 2020: Education leavers in the current crisis.

Monitor, ILO (2020). COVID-19 and the world of work. Updated estimates and analysis.

OECD (2020), “Youth and COVID-19 Response, Recovery and Resilience”.

Partners Albania for Change and Development. (2021). The impact of COVID-19 on youth employment in Albania.

Tamesberger, D., \& Bacher, J. (2020). COVID-19 Crisis: How to Avoid a 'Lost Generation'. Intereconomics, 55(4), 232-238.

Teräs, M., Suoranta, J., Teräs, H., \& Curcher, M. (2020). Post-Covid-19 education and education technology 'solutionism': A seller's market. Postdigital Science and Education, 2(3), 863-878. 